\title{
Rechtsgeschichte
}

http://www.rg-rechtsgeschichte.de/rg4

$\operatorname{Rg} 42004 \quad 28-37$

Zitiervorschlag: Rechtsgeschichte Rg 4 (2004)

http://dx.doi.org/10.12946/rg04/028-037

\section{Bartolomé Clavero}

\section{Claiming for History: An American Hard Case}




\section{Abstract}

The essay attempts an experiment in method for constitutional history. If Constitutions of the Americas are read and construed in a positive way as present instruments, one misses both past and current legal meanings. You really miss law in force. History is embedded in constitutional texts. Here, in this essay, illustration is twofold: grant of religious freedom on the one hand and state power over archaeological sites on the other. Rather illustration is unique, as far as the latter may establish the means to deprive indigenous peoples of their religious shrines, provided that their religions are not constitutionally deemed human cultures, but inhuman superstitions. No need to guess. Constitutional take-off is telling. Even the plainest textual sequence makes the close link between state empowerment and indigenous deprivation apparent. To be sure, indigenous peoples are mentioned by constitutions, yet as wards to be protected rather than subjects entitled to freedom. History always helps to know what is still hidden in living law or not so hidden if all the not-so-dead past is taken into account. 


\section{Claiming for History: An American Hard Case}

Kaytaqa jatun tantakuypi, tukuynin llajtasmanta ujllachasqa runa qhelqerqanku, imakunachus kay pachapi atiyninghej kasqanta yachananchejpaj ...

Whereas recognition of the inherent dignity and of the equal and inalienable rights of all members of the buman family is the foundation of freedom, justice and peace in the world...

Considerando que la libertad, la justicia y la paz en el mundo tienen por base el reconocimiento de la dignidad intrinseca y de los derechos iguales e inalienables de todos los miembros de la familia humana ...

Universal Declaration of Human Rights

(Quechua, English, and Spanish)

Throughout America, constitutions in force today often recognize the presence and certain rights of indigenous peoples, indigenous peoples taken in the sense uttered by an international treaty such as the 1989 International Labour Organisation Convention Concerning Indigenous and Tribal Peoples: »Peoples in independent countries who are regarded as indigenous on account of their descent from the populations which inhabited the country, or a geographical region to which the country belongs, at the time of conquest or colonisation or the establishment of present state boundaries and who, irrespective of their legal status, retain some or all of their own social, economic, cultural and political institutions «. So far, States in America have mostly ratified this multilateral treaty. ${ }^{\mathbf{I}}$

Specific constitutional sections in America deal with indigenous rights. However, constitutions are not usually further amended or reviewed on the latter's behalf. Therefore, I aim to tackle the unreformed part - the larger and essential share. I shall question whether history can help with the reading, understanding, and construction of the whole of current constitutions, not just specific sections, as regards indigenous rights - the rights of peoples who as polities may pre-exist the very States. In brief, what is the use of legal history for constitutional indigenous understanding? It is an unusual query in both research and teaching at Latin and Anglo American law schools by either constitutionalists or historians.

For brevity's sake, we need just one sample. Let it be Panama. I have chosen some constitutional statements among those that make no direct reference to indigenous people. The issue may be twofold: freedom of religion and archaeological sites. The Panamanian Constitution recognizes the former and nationalizes the latter. ${ }^{2}$ On the one hand it grants religious freedom and on the other it takes archaeological sites into the public sector as matters of fact and law not concerning indigenous people. What have these statements to do with them? At first glance, nothing at all, or maybe something, as long as it might be assumed first that every Panamanian citizen, indigenous or non-indigenous, is entitled to freedom of religion and secondly that all this citizenship benefits from the care and management of the archaeological heritage by the Republic of Panama, their State. Should we take both readings for granted? Let us check texts. Let us excavate in a constitutional site. Let us go at once constitutionalist and archaeologist. Let us be historians.

When Panama became independent from Colombia at the beginning of the 2oth century under the impulse and protection of the United States, religious freedom was granted, but its first Constitution excluded non-Christianised

I Anmerkungen s. Seite $34 \mathrm{ff}$. 
indigenous people from enjoyment of the same by funding and empowering Catholic missions to convert them. The same clause stated both freedom on behalf of non-indigenous people and the obligation for indigenous people to withdraw their own beliefs and practices. So it was for the Panamanian constitutionalism from 1904 to $1972 .{ }^{3}$ Implicitly, a kind of rationale operated. For the non-indigenous constitutional party, Christian religions were thought to be civilisation and non-Christian religion barbarism or no religion at all. Since 1972, has the constitutional silence on such discrimination terminated indigenous exclusion? You can never be sure. Today, the Panama Constitution recognizes the different "cultural patterns « of indigenous peoples, yet it refers to the need for "cultural change through scientific methods «, thus substituting the missionary way. ${ }^{4}$ No comment. History is revealing. You need its help to read between the constitutional lines. You may also notice the continuous phrasing on Christian framework encroaching on freedom up to the present. ${ }^{5}$

On the other hand, when archaeological sites were nationalized by the I94I Panama Constitution, the normative language also made some reference to indigenous people: "The indigenous guacas belong to the Republic of Panama «. ${ }^{6}$ Guaca, also spelled huaca, is a clue. It is a word used in America, mainly throughout the Andes, by Spanish speakers, but it does not belong to the tongue handed down by Spain. It is Quechua or Runasimi, coming to Panama through Colombia. Among American Spanish speaking people, guaca really means ancient ruins and remains or also hidden treasures and even personal savings or dirty money kept out of the reach of government and banks. In Quechua, it holds a prior meaning, naming places and structures where distinguished ancestors are buried, venerated artefacts are saved, congregational meetings are hold, cultural identities are performed, or relief from suffering and resort for rest are furnished. Guacas are sacred indigenous sites, Quechua or not (there are no Quechua people in Panama). They continue to be so even when assaulted and ruined by alien people. If you cannot move to the Andes and gain the confidence of some individuals among the over ten million Quechua-speaking people in order to become duly informed, there are publications and addresses to be profitably visited, although they would by no means substitute local knowledge. History always helps. ${ }^{7}$

When the Republic of Panama Constitution nationalized guacas, indigenous peoples were expropriated or rather colonial prior expropriation under Spanish rule was thus finally constitutionalized. Yet, only the right of private proprietors - non-indigenous landowners - was taken into consideration in order to be duly compensated, just as if indigenous peoples did not exist or, at least, were not entitled to rights. ${ }^{8}$ Rather the latter was the case. Remember the terms of the constitutional recognition of religious freedom. As long as they remained nonChristian, by frequenting their sacred places for instance, indigenous people were not entitled to liberty. They had to be under the control of Catholic missions backed and funded by the constitutional Republic. Thus, for constitutions, guacas could not be religious sites, but only archaeological remains. They could not be indigenous possessions or even heritage. Actually, for constitutions, for their set of freedoms, regarding conscience, ownership and maybe so all the rest, indigenous peoples did not exist. Needless to say that Catholic and other Christian churches and sacred places were not expropriated. 
Are we facing constitutional contradictions or rather some kind of constituent rationale, so to speak? So far, we know that the latter may be the case. History opens your eyes. Some logic lay in the double standard concerning religious freedom and access to shrines. The rationale may now be overlapped but it was quite diaphanous in past constitutional language. Religion did not mean any religion. People who made constitutions in America bore in mind on the one hand religion entitled to freedom and on the other superstition needing conversion, this is the EuroAmerican civilization to be expanded and the Indo-American barbarism to be eradicated, culture and its lack all in the singular. The entire set of constitutional freedoms might be regarded in the light of this discrimination between nonindigenous and indigenous peoples, against the latter, on cultural tenets prior to legal terms. Hence, the constitutional wording may not encompass indigenous religions. ${ }^{9}$

The incumbent question is whether the discriminatory construct trembles and falls once the language recedes and shifts. The Constitution of Panama currently registers freedom of conscience on the one hand and nationalization of archaeological sites on the other without any indigenous reference for any of these items. Does it make a difference? Is it the end of this story? Did the dichotomy vanish when the double standard disappeared from the constitutional phrasing? Have constitutions therefore become straightforward? Is the problem over? It does not seem so. We must yet learn from history. Present reading does not grasp actual meaning. Aside from other lightness and sightlessness, the history-blind Constitution does not manifest the import of its standing deficit of freedoms. ${ }^{\text {Io }}$

In the current constitutional text of Panama, nothing is said about either the indigenous ex- clusion from religious freedom or their deprivation of sacred guacas, yet the signs are still there. The State is the owner and manager of the socalled archaeological sites. Christendom places limits to freedom. Past layers may be alive in present text as a pervading shadow constitution. Derogatory references are cancelled, but not counteracted. We should not take constitutional statements at their face value. Eventual recognition of indigenous cultures and rights, so usual nowadays throughout America, comes as a kind of interpolation to constitutions not amended in their entirety on the behalf of this not so new human presence. Even so, with its novelty and all, ${ }^{\text {II }}$ the Panamanian Constitution provides for policy to achieve the "cultural change « of indigenous communities »through scientific methods «, as we know. Sciences such as anthropology and politics receive the baton from religious missions in the relay race to convert indigenous people. Might instead history counteract the constitution? Yet, is there such a divide between history and law?

Let us take into account a third constitutional pronouncement not directly referring to indigenous people. I mean the generic provision on territorial structure of the Republic of Panama allowing "special regimes « or, in past constitutions since I94I, »special territories « as exempted from the common division into provinces and districts. No much wonder that it is a formula for accepting, on sufferance, the indigenous resistance to the political presence and organisation of the Republic of Panama. The Constitution says that "the special regime may be created by statute « - by Panamanian legislation - but peoples are the producers of that very speciality through their opposition to the State. "Special territories « turn out to be indigenous territories. Constitutional creation is mere pretension. ${ }^{\mathbf{I 2}}$ 
It is the visible tip of a submerged iceberg. Today, within the State frontiers, there are indigenous polities even supporting their »special regime " in international standards regarding peoples' rights rather than Panamanian laws branded by them as still colonialist. As the I989 International Labour Organisation Convention Concerning Indigenous and Tribal Peoples calls to mind, these peoples are older than the State itself. They descend »from the populations which inhabited the country (...) at the time of conquest or colonisation or the establishment of present state boundaries «.

The Embera-Wounaan is one of these peoples. Their Carta Orgánica, the organic charter enacted by the Embera-Wounaan Congress in I993, though dependent upon Panamanian legislation, reads thus in its preamble: »During the last 500 years non-indigenous people have set the law for indigenous people, implying the systematic violation of the indigenous peoples' rights (...). The law in force in Panama keeps this derogatory and undemocratic nature, so a dramatic turn of the legal approach to the standing of indigenous peoples is badly needed in order to actually favour the entitlement, exercise and enjoyment of their fundamental rights. Thus, in the present realm of international law with both the Organization of the American States and the United Nations Organization, declarations and conventions for the warrant of the Human Rights of the Indigenous Peoples and their legal and political systems are in progress «. ${ }^{\mathbf{1 3}}$ Thus we meet a side of history not usually taken into account at law schools even throughout America, though it ought to be of deep concern to constitutionalism itself. It is the dark side of that same constitutional history.

There may be both constitutional history and law outside and at the expense of the very constitutions. There are constitutional rights through counter-constitutional history, so to say. The signs are etched in the same constitutional documents, but you are in need of history, both indigenous and non-indigenous, to read them. In fact, since independence took place under the direct influence of the United States on behalf of the inter-hemispherical canal, Panama has tried to follow the example displacing and confining indigenous peoples into reservations. The ward did it less successfully than the sponsor. Colombia, from which Panama seceded, had made the first constitutional move in I8I I putting indigenous areas on the same level with inhabited lands, as terrae nullius according to the contemporaneous law of nations, ${ }^{\mathbf{I} 4}$ as if these peoples were not there or ought not to exist anywhere, later adopting the United States formula of territories under especial rule. Thus, Panama inherited the know-how from both its sponsor or rather godfather and its mother country, Colombia. As for the same constitutional device, Spain was only one of the grandmothers, the other one being the Catholic Church. ${ }^{\mathrm{I}}$

In the case of Colombia, including Panama, as regards indigenous peoples, the constitutional starting off was much more complex. The I8 I I Colombian Constitution, then called of Nueva Granada (Columbus' name would come later), began by considering indigenous territories nullius, yet it added that the "wandering tribes or nations of uncivilised Indians " were supposed to be treated on friendly terms according to »Christian love«. Thus, »treaties and settlements « might be agreed with them in order »to protect their rights through the humanity and philanthropy required from us given their present state of imbecility “. ${ }^{\mathbf{I} 6}$ Treaties existed so far. Before Latin American independence, the Spanish Mon- 
archy had both conquered indigenous peoples and settled agreements implying mutual recognition with those who successfully resisted colonial invasion. Peoples within the hypothetical frontiers of former Colombia and latter Panama, such as the Kuna, had signed treaties. ${ }^{17}$ Hence, when independence was about to occur, they might consider themselves on legal grounds legal for both parties - as distinct polities regarding the people who came from Europe and expanded through America or, in Kuna language, Abya Yala.

The first Constitution of Colombia or Nueva Granada referred to treaties with indigenous peoples but it did not recognize the force of the existing ones. Assumptions might somehow differ. According to constitutional phrasing, the treaties with Indians were to be framed on definitively unequal terms so as to submit them to civilisation and therefore to the State. Independence discontinued treaties. Pretending to be founding, they ignored existing agreements. On the contrary, without creating pretensions, from the indigenous viewpoint, non-indigenous constitutions could not recognize their rights as long as they did not treat them as distinct and equal, existing polities. Since the first contact in the I6th century up to the present, against all the odds, peoples such as the Kuna have maintained this stance in the face of Spanish, Colombian, and Panamanian colonial duress. Thus, they keep their own law and jurisdiction along with their side of the history - legal history too. ${ }^{\mathrm{I} 8}$

Indigenous narrative is an account you need in order to understand the constitutions, past or present, which resolutely ignore an entire and fundamental side of the history or even succeed in becoming blind and unaware nowadays. From the Embera-Wounaan and Kuna peoples we have learnt that the badly needed history is longer and broader than the strictly constitutional one. Concerning non-Euro-American people, constitutionalism did not discontinue colonialism. As for them, the former could even worsen the latter. Whatever the case may be, just to know and also to handle present law, we need to advance the historical research dealing with the colonial era into constitutional times. ${ }^{\mathbf{} 9}$

Current one-sided history may be shocked now, but it has the very evidence to hand. Astonishment goes together with awareness given that the issue of indigenous presence is disregarded by usual constitutional history. Legal history in America takes into consideration cultures in the plural and even a clash of them, yet exclusively between Latin and Anglo parties as if indigenous peoples could not inherit, develop, and stand up for their own, plural cultures regarding history and law, narratives and polities. ${ }^{20}$ As for constitutionalism, it did not begin in America with the Constitution of Nueva Granada, to be sure. It did not even start off in any place of the part we now call Latin America.

Nonetheless, the starting moment was not more brilliant at all. The founding fathers of the United States introduced indigenous peoples to constitutional time as literal foes. ${ }^{2 \mathbf{I}}$ There, in the final 1787 Constitution, the arithmetic for constituency was indeed consistent, counting free man as one; slave-owner as more than one; and Indian as naught. ${ }^{22}$ As regards the latter, the nullifying phrasing would be reiterated when the Constitution was to be amended after abolition of slavery. ${ }^{23}$ No constitutional amendment on behalf of indigenous people has ever taken place. Indian United States citizenship would come through statute without their consent as peoples. ${ }^{24}$ All this is the tip of an iceberg of invasion, deprivation, harassment, confinement, subjugation, and even slaughter by legal and even con- 
stitutional means. Heed the qualifying adjectives. $^{25}$

The brother founders of Latin American States joined right away with constitutions assuming that conscience and other things in life might be a matter of human freedom for all citizens but indios, the indigenous people, so they were supposed to give up creeds and riches, together with their own polities, their law and jurisdiction, to actually share constituency and enjoy rights. ${ }^{26}$ They were supposed to become human handing over occupancy of territories, ways of life, and control of themselves. Otherwise, what they and their domains were thought to need was guardianship from States, not entitlement of rights. Protection rather than freedom would be again the constitutional formula for indigenous peoples when States throughout America come to realize that they have not given up. ${ }^{27}$

Throughout America, Latin and Anglo, very few States have no constitutional say, either past or present, regarding indigenous peoples. Chile is the most significant case. From the first to the current Constitution, from I 822 to $200 \mathrm{I}$ (the year of the last amendment), there is no constitutional trace of indigenous existence through Chilean constitutionalism. Silence may be a way of saying. What does it mean in that case? In fact, since the 1822 Constitution, Chile had defined its frontiers including indigenous territories and even disregarding colonial boundaries previously recognized by the Spanish Monarchy. ${ }^{28}$ Constitution discontinued treaties. Silence cancelled peoples. It might imply genocide more definitely than the terra nullius rule. Both meant the constitutional aim of outlawing and outrighting peoples as far as they retained their own cultural and territorial existence. First constitutions were talkative, seeming varied yet sharing intent. ${ }^{29}$ For indigenous polities, constitutional silence was no more rewarding or less derogatory than all the set of mentions. History shows and teaches. Historians may evince and elucidate.

Behind every constitutional statement in America, throughout a whole continent where colonialism has not been discontinued by constitutionalism, there may lurk a deprivation of indigenous rights. Constitutions are not plain texts, but archeological palimpsests. What about the constitutional premise of the separation of powers - legislative, executive, and judiciary? I mean what about the very empowering of inclusive States to take charge of law, government, and justice affecting indigenous polities as in the case of all America, Latin and Anglo? The constitutional statements mostly concerning them are not in need of any mention. Silence helps and suffices. When clauses of recognition are finally added, constitutional layers blatantly contradict each other. ${ }^{30}$ Do we not badly need history to read and work, realize and construe? The first legal point is a historical question: in what way and to what extent indigenous right precedes State constitution? Law and history at once have been tested by the twofold American issue. $^{3 \mathbf{3}}$

De tota America, Latina Anglicaque, fabula narratur? If so, we face a real hard case from the very beginning of the suitable proceedings. History rather than law has the capacity to play the part of the grand jury. And history seems to call constitutions themselves into question. Whatever the final outcome may be, we are in dire need of unbiased historical research and teaching not discontinuing the present. Present is history and so it must be treated even by lawyers. Otherwise, we will be unable to understand the meaning and reach of the law in force. Unless 
you like and choose pretension and delusion, fake and deceit, make-believe and right-depriving, the very divide between legal and historical spheres is absolutely unadvisable. It would simply be the first, deepest bias.

Bartolomé Clavero*

* Professor für römisches Recht, Rechtsgeschichte, Staats- und Kirchenrecht an der Universität Sevilla clavero@us.es

Notes

i Cletus Gregor Barié, Pueblos indígenas y derechos constitucionales en América Latina. Un panorama, Instituto Indigenista Interamericano, 2000 (updated edition forthcoming); MARCO Aparicio, Los pueblos indígenas y el Estado. El reconocimiento constitucional de los derechos indígenas en América, Centro de Estudios de Derecho, Economía y Ciencias Sociales, 2002.

2 Panama Constitution, III (Derechos y Deberes Individuales y Sociales), I (Garantías Fundamentales), 35: "Es libre la profesión de todas las religiones, así como el ejercicio de todos los cultos, sin otra limitación que el respeto a la moral cristiana y el orden público. Se reconoce que la religión católica es la de la mayoría de los panameños «; IX (La Hacienda Pública), I (Bienes y Derechos del Estado), 254: "Pertenecen al Estado: 8. Los sitios y objetos arqueológicos, cuya explotación, estudio y rescate serán regulados por la Ley. « Constitutions are available on Internet: http://www.georgetown.edu/pdba/ and extending to past Latin American Constitutions: http://cervantesvirtual.com/portal/ constituciones.

3 Jorge Fábrega (ed.), Constituciones de la República de Panamá, Imprenta Nacional, I963. I904 Constitution, 26: "Es libre la profesión de todas las religiones ... Se reconoce que la Religión Católica es la de la mayoría de los habi- tantes de la República, y la Ley dispondrá se le auxilie ... para misiones a las tribus indígenas ", likewise, with lesser variants, in I94 I and I946 Constitutions. As for the continuity of phrasing, check the just quoted article 35 of the present Constitution.

4 Panama Constitution, III (Derechos y Deberes Individuales y Sociales), IV (Cultura Nacional), 86: „El Estado reconoce y respeta la identidad étnica de las comunidades indígenas nacionales, realizará programas tendientes a desarrollar los valores materiales, sociales y espirituales propios de cada uno de sus culturas y creará una institución para el estudio, conservación, divulgación de las mismas y de sus lenguas, así como la promoción del desarrollo integral de dichos grupos humanos «; V (Educación), I04: "El Estado desarrollará programas de educación y promoción para grupos indígenas ya que poseen patrones culturales propios, a fin de lograr su participación activa en la función ciudadana «; VIII (Régimen Agrario), I 22: "... La política establecida para este Capítulo será aplicable a las comunidades indígenas de acuerdo con los métodos científicos de cambio cultural."

5 Panama Constitution, 35: "... sin otra limitación que el respeto a la moral cristiana y el orden público. Se reconoce que la religión católica es la de la mayoría de los panameños «, already quoted; but, previously, I9: »No habrá fueros o privilegios especiales ni discriminación por razón de raza, religión o ideas políticas. «Does religión really mean every religion on an equal footing at last?

6 I94 I Constitution, I45: »Pertenecen a la República de Panamá: 6. Las guacas indígenas, cuya exploración y explotación serán reguladas por la Ley «, and likewise I946 Constitution, 208.

7 Gordon Brotherston, Book of the Fourth World: Reading the Native Americas through their Literature, Cambridge: Cambridge University Press I992, 28-39, I93-2I I; WALTER D. Mignolo, The Darker Side of the Renaissance: Literacy, Territoriality, and Colonization, Ann Arbor, Michigan: University of Michigan Press I995, I25-I69, 289-3I3; Kenneth J. Andrien, Andean Worlds: Indigenous History, Culture, and Consciousness under Spanish Rule, I 532-I825, Albuquerque: University of New Mexico Press 2001.

8 I94I Constitution, I47: "Sobre los bienes comprendidos en [el ordinal] $6^{\circ}$ del artículo I $45 \ldots$, con respecto a los cuales existan al tiempo de entrar a regir esta reforma constitucional derechos de propiedad privados adquiridos conforme a la legislación anterior, sus propietarios actuales conservarán el dominio útil ..., pero la nuda propiedad revertirá al Estado sin indemnización alguna ..." (the reference is quoted); 1946 Constitution, 210: »Los propieta- 
rios actuales [de guacas] ..., con respecto a los cuales existan derechos de propiedad legítimamente adquiridos al tiempo de entrar a regir esta Constitución, conservarán el dominio útil durante veinte años ..., pero dicha propiedad revertirá al Estado sin indemnización ...«

9 Panama Constitution, 36: "Las asociaciones religiosas tienen capacidad jurídica y ordenan y administran sus bienes dentro de los límites señalados por la ley, lo mismo que las demás personas jurídicas «, a provision construed as encompassing asociaciones religiosas indigenous associations only if Christian or Christianized.

Io For the case of the freedom's law of Panama as history-blind, you may check the approach from a party acting as a universal, unilateral jury: www.state.gov/g/drl/rls/ irf/2002/I 4053.htm (U.S. Department of State, Bureau of Democracy, Human Rights, and Labor, International Religious Freedom Report. 2002, Panama).

I I Panama Constitution, 86 already quoted; I 23: »El Estado garantiza a las comunidades indígenas la reserva de las tierras necesarias y la propiedad colectiva de las mismas para el logro de su bienestar económico y social. La Ley regulará los procedimientos que deban seguirse para lograr esta finalidad y las delimitaciones correspondientes dentro de las cuales se prohíbe la apropiación privada de las tierras «; I 4 I: »La Asamblea Legislativa se compondrá de los Legisladores que resulten elegidos en cada Circuito Electoral, de conformidad con las bases siguientes: 5. Cada Circuito Electoral tendrá un máximo de cuarenta mil habitantes y un mínimo de veinte mil habitantes, pero la Ley podrá crear Circuitos Electorales que excedan el máximo o reduzcan el mínimo anteriores para tomar en cuenta las divisiones políticas actuales, la proximidad territorial, la concentración de la población indígena, los lazos de vecindad, las vías de comunicación y los factores históricos y culturales, como criterios básicos para el agrupamiento de la población en Circuitos Electorales.»
I2 Panama Constitution, I (El Estado Panameño), 5: »El territorio del Estado panameño se divide políticamente en Provincias, éstas a su vez en Distritos y los Distritos en Corregimientos. La ley podrá crear otras divisiones políticas, ya sea para sujetarlas a regímenes especiales o por razones de conveniencia administrativa o de servicio público«; 1946 Constitution, 5: El territorio de la República se divide en municipios autónomos agrupados en provincias. La ley podrá crear comarcas sujetas a regímenes especiales ..." I94 I Constitution, 5: »El territorio de la República se divide en Provincias y Distritos ... La Ley podrá crear Comarcas sujetas a regímenes especiales."

I3 Derechos de los Pueblos Indígenas, Servicio Central de Publicaciones del Gobierno Vasco, I998, 503-560. For references, S. JAMES Anaya, Indigenous Peoples in International Law, New York, Oxford: Oxford University Press I996.

I4 Diego Uribe Vargas (ed.), Las Constituciones de Colombia, Instituto de Cooperación Iberoamericana, I985. I8I I Constitution, 23: "Queda a la generosidad de las Provincias la cesión de aquellas tierras baldías que existen dentro de sus límites conocidos y habilitados de sus territorios, y que algún día, con la naturalización de extranjeros, o aumento de la población, pudieran producir un fondo considerable al Congreso; pero se reputarán indisputablemente de éste todas las que hoy se pueden considerar nullius por estar inhabitadas y fuera de los límites conocidos de las mismas Provincias, aunque comprendidas bajo la demarcación general del Reyno [de Nueva Granada] y de sus líneas divisorias con otras potencias y estados, o antiguos virreinatos, tales como las que bañan el alto Amazonas, Napo, Putumayo, Caquetá, Guaviare y otros ríos que descargan en el primero, o en el grande Orinoco, y en donde a su tiempo se establecerán nuevas poblaciones que hagan parte de esta Unión, a donde por lo menos conviene mantener lugares fronterizos que nos deslin- den y dividan de las naciones vecinas que hoy ocupan la costa oriental de la América meridional."

I 5 I 853 Constitution, 47: "... Las secciones territoriales de la Goajira, el Caquetá y otras que no estén pobladas por habitantes reducidos a la vida civil, pueden ser organizadas y gobernadas por leyes especiales «; 1863 Constitution, 78 : "Serán regidos por una ley especial los territorios poco poblados u ocupados por tribus de indígenas. "In fact, on more colonial terms, the territorial formula had early been somehow adopted by the I8I 2 Spanish Constitution (335.ro: "Las diputaciones de las provincias de ultramar velarán sobre la economía, orden y progreso de las misiones para la conversión de los indios infieles ...«), which was put into practice in Mexico, Central America and Peru, but directly not in Colombia, where Panama was then included. United States references, including some more involved and specific historiography, come later.

I 6 I 8 I I Constitution, 24: "No por esto [terra nullius] se despojará ni se hará la menor vejación o agravio a las tribus errantes o naciones de indios bárbaros que se hallen situadas o establecidas dentro de dichos territorios; antes bien se las respetará como legítimos y antiguos propietarios, proporcionándoles el beneficio de la civilización y religión por medio del comercio y por todas aquellas vías suaves que aconseja la razón y dicta la caridad cristiana, y que sólo son propias de un pueblo civilizado y culto; a menos que sus hostilidades nos obliguen a otra cosa «; 25 : "Por la misma razón podremos entrar en tratados y negociaciones con ellos sobre estos objetos, protegiendo sus derechos con toda la humanidad y filosofía que demanda su actual imbecilidad, y la consideración de los males que ya les causó, sin culpa nuestra, una nación conquistadora «; 26: »Pero si dentro de los límites conocidos de las Provincias, o entre Provincia y Provincia, hubiera naciones de esta clase ya establecidas que hoy pudieran hacer cómodamente parte de esta Unión o de las mis- 
mas Provincias, principalmente cuando ya no las aterra un tributo ignominioso, ni un gobierno bárbaro y despótico, como el que ha oprimido a sus hermanos por trescientos años, se las convidará y se las atraerá por los medios más suaves, cuales son regularmente los del trato y comercio, a asociarse con nosotros, y sin que sea un obstáculo su religión, que algún día cederá tal vez el lugar a la verdadera, convencidos con las luces de la razón y del evangelio que hoy no pueden tener.

i7 Abelardo Levaggi, Diplomacia hispano-indígena en las fronteras de América. Historia de los tratados entre la Monarquía española y las comunidades aborígenes, Centro de Estudios Políticos y Constitucionales, 2002, 304-309 (the one-sided, Spanish version of the I787 Treaty with the Kuna people); David J. Weber, Bourbons and Bárbaros: Center and Periphery in the Reshaping of Spanish Indian Policy in: Negotiated Empires: Centers and Peripheries in the Americas, I 500-I 820 , ed. by Christine Daniels and Michael V. KENNEDY, London: Routledge 2002, 79-IO3 (99: »Its [I787 Treaty's] language in Spanish suggests that the Cunas had surrendered, declaring themselves vassals of the Crown and agreeing not to trade with foreigners. It seems unlikely, however, that the Cunas saw it as a surrender ... «; IOI: "Whatever Spaniards thought of the gifts they offer, some Indians beneficiaries of Spanish largesse probably understood Spanish payment as tribute", for another example of the twosided history we are in need of).

i 8 James Howe, A People Who Would Not Kneel: Panama, the United States, and the San Blas Kuna, Washington: Smithsonian Institute Press I998.

I9 Regarding peoples in Mexico, NANCY M. FARRISs, Maya Society and Colonial Rule: The Collective Enterprise of Survival, New Jersey: Princeton University Press I 984; JAMES LockHaRT, The Nahuas After the Conquest: A Social and Cultural History of the Indians of Central Mexico, Sixteenth Through Eighteenth
Century, Stanford, California: Stanford University Press 1992. 20 Morris S. Arnold, Unequal Laws unto a Savage Race: European Legal Traditions in Arkansas, I686-1836, Fayetteville: The University of Arkansas Press I 985 ; David J. LANGUM, Law and Community on the Mexican California Frontier: Anglo-American Expatriates and the Clash of Legal Traditions, I $82 I-I 846$, Norman: University of Oklahoma Press I987; Charles R. Cutter, The Legal Culture of Northern New Spain, I700-I 8 Iо, Albuquerque: University of New Mexico Press I995.

2I I78 I Articles of Confederation of the United States, 6: "... No State shall engage in any war without the consent of the United States in Congress assembled, unless such State be actually invaded by enemies, or shall have received certain advice of a resolution being formed by some nation of Indians to invade such State, and the danger is so imminent as not to admit of a delay till the United States in Congress assembled can be consulted ..."

22 United States Constitution, I787, I. 2(3): »Representatives and direct taxes shall be apportioned among the several States which may be included within this Union, according to their respective numbers, which shall be determined by adding to the whole number of free persons, including those bound to service for a term of years, and excluding Indians not taxed, three fifths of all other persons « (being other persons the slaves adding points for their masters' sake; and you may wonder why is it that Indians not taxed were named to be excluded if they did not belong to the United States polity).

23 United States Constitution, Amendment XIV, I 868, 2: "Representatives shall be apportioned among the several states according to their respective numbers, counting the whole number of persons in each state, excluding Indians not taxed ..."

24 I924 Act to Authorize the Secretary of the Interior to Issue Certificates of Citizenship to Indians:
»Be it enacted by the Senate and House of Representatives of the United States of America in Congress assembled that all non-citizen Indians born within the territorial limits of the United States be, and they are hereby, declared to be citizens of the United States ..."

25 Sidney L. Harring, Crow Dog's Case: American Indian Sovereignty, Tribal Law, and United States Law in the Nineteenth Century, Cambridge: Cambridge University Press I994; Francis Paul Prucha, American Indian Treaties: The History of a Political Anomaly, Berkeley: University of California Press I994; JiLl NoRGREN, The Cherokee Cases: The Confrontation of Law and Politics, McGraw-Hill Case Studies in Constitutional History, I995; Robert A. Williams Jr., Linking Arms Together: American Indian Treaty Visions of Law and Peace, I600-I 800, New York: Oxford University Press I997; DAvid E. WILKINS, American Indian Sovereignty and the U.S. Supreme Court: The Masking of Justice, Austin: University of Texas Press I997; Blue Clark, Lone Wolf v Hitchcock: Treaty Rights and Indian Law at the End of the Nineteenth Century, Lincoln:

University of Nebraska Press I999; Vine Deloria, Jr. and D. E. Wilkins, Tribe, Treaties, and Constitutional Tribulations, Austin: University of Texas Press I999; Ward Churchill, Perversions of Justice: Indigenous Peoples and Angloamerican Law, San Francisco: City Lights Books 2003.

26 As a telling example, I8II Venezuela Constitution, 200: "Como la parte de ciudadanos que hasta hoy se ha denominado indios no ha conseguido el fruto apreciable de algunas leyes que la monarquía española dictó a su favor, porque los encargados del Gobierno en estos países tenían olvidada su ejecución; y como las bases del sistema de Gobierno que en esta Constitución ha adoptado Venezuela no son otras que las de la justicia y la igualdad, encarga muy particularmente a los Gobiernos provinciales que así como han de 
aplicar sus fatigas y cuidados para conseguir la ilustración de todos los habitantes del estado, proporcionarles escuelas, academias y colegios en donde aprendan todos los que quieran los principios de Religión, de la sana moral, de la política, de las ciencias y artes útiles y necesarias para el sostenimiento y prosperidad de los pueblos, procuren por todos los medios posibles atraer a los referidos ciudadanos naturales a estas casas de ilustración y enseñanza, hacerles comprender la unión íntima que tienen con todos los demás ciudadanos, las

consideraciones que como aquellos merecen del Gobierno y los derechos de que gozan por sólo el hecho de ser hombres iguales a todos los de su especie, a fin de conseguir por estos medios sacarlos del abatimiento y rusticidad en que los ha mantenido el antiguo estado de las cosas y que no permanezcan por más tiempo aislados y aun temerosos de tratar a los demás hombres, prohibiendo desde ahora que puedan aplicarse involuntariamente a prestar sus servicios a los Tenientes o Curas de sus parroquias, ni a otra persona alguna, y permitiéndoles el reparto en propiedad de las tierras que les estaban concedidas y de que están en posesión, para que a proporción entre los padres de familia de cada pueblo las dividan y dispongan como verdaderos señores, según los términos y reglamentos que formen los gobiernos provinciales."

27 Bartolomé Clavero, Ama Llunku, Abya Yala. Constituyencia indígena y código ladino por América, Centro de Estudios Políticos y Constitucionales, 200I, I9-7I.

28 I822 Chile Constitution, 3: "El territorio de Chile conoce por límites naturales: al sur, el Cabo de Hornos; al norte, el despoblado de Atacama; al oriente, los Andes; al occidente, el mar Pacífico. Le pertenecen las islas del Archipiélago de Chiloé, las de la Mocha, las de Juan Fernández, la de Santa María y demás adyacentes « (so ignoring the colonial frontier with the $\mathrm{Ma}$ puche people along the Bío Bío river). Later, the uti possidetis rule and international law in the general will help, further disregarding indigenous polities.

29 I8I9 Argentina Constitution, I 28: "Siendo los indios iguales en dignidad y en derechos a los demás ciudadanos, gozarán de las mismas preeminencias y serán regidos por las mismas leyes. Queda extinguida toda tasa o servicio personal baxo cualquier pretexto o denominación que sea. El Cuerpo Legislativo promoverá eficazmente el bien de los naturales por medio de leyes que mejoren su condición hasta ponerlos al nivel de las demás clases del Estado." I824 Mexico Constitution, 50: "Las facultades exclusivas del congreso general son las siguientes: II. Arreglar el comercio con las naciones extranjeras, y entre los diferentes estados de la federación y tribus de los indios" (translating from the United States Constitution, I. 8: "The Congress shall have power: 3 : To regulate commerce with foreign Nations, and among the several States, and with the Indian tribes «). 1828 Peru Constitution, 75: "Son atribuciones de estas Juntas [Departamentales]: Io. Entender en la reducción y civilización de las tribus de indígenas limítrofes al departamento, y atraerlos a nuestra sociedad por medios pacíficos." I 830 Ecuador Constitution, 68: »Este Congreso constituyente nombra a los venerables curas párrocos por tutores y padres naturales de los indios, excitando su ministerio de caridad en favor de esta clase inocente, abyecta y miserable." 1838 Guatemala Declaration of Rights, 3: "Aunque todos los hombres tienen por naturaleza iguales derechos, su condición en la sociedad no es la misma ... Para fundar y mantener el equilibrio social, las leyes amparan al débil contra el fuerte, y por esta necesidad en todas las naciones, aun las menos cultas, son protegidas particularmente aquellas personas que por su sexo, edad o falta de capacidad actual, carecen de ilustración suficiente para conocer y defender sus propios derechos. Por tanto, hallán- dose la generalidad de los indígenas en este último caso, las leyes deben protegerlos a fin de que se mejore su educación; de evitar que sean defraudados de lo mejor que les pertenece en común o en particular; y que no sean molestados en aquellos usos y habilidades aprendidos de sus mayores, y que no sean contrarios a las buenas costumbres. « And so on.

30 As an example - just one - of the common current contradiction between State justice and indigenous jurisdiction, Peru Constitution, I 3 8: »La potestad de administrar justicia emana del pueblo y se ejerce por el Poder Judicial a través de sus órganos jerárquicos ... «; I 39: "Son principios y derechos de la función jurisdiccional: I. La unidad y exclusividad de la función jurisdiccional «; I 49: »Las autoridades de las Comunidades Campesinas y Nativas, con el apoyo de las Rondas Campesinas, pueden ejercer las funciones jurisdiccionales dentro de su ámbito territorial de conformidad con el derecho consuetudinario, siempre que no violen los derechos fundamentales de la persona. La ley establece las formas de coordinación de dicha jurisdicción especial con los Juzgados de Paz y con las demás instancias del Poder Judicial." Qualifying comunidad, campesina means Quechua and Aymara; nativa, belonging to diverse indigenous peoples in the Amazon basin; rondas campesinas are communitarian vigilante groups, indigenous or not. Ley, meaning statute, may either further subordinate community to State or encapsulate the former, yet it cannot resolve the clash of jurisdictional principles, constitutional versus communitarian. This is not up to one of the parties by itself, to be sure.

3i Tony Simpson, Indigenous Heritage and Self-Determination: The Cultural and Intellectual Property Rights of Indigenous Peoples, International Work Group for Indigenous Affairs, I997; Encuentro Nacional de los Pueblos Indígenas de México, Derechos religiosos y pueblos indigenas, Instituto $\mathrm{Na}-$ cional Indigenista, I 998. 